\title{
Opportunities and Challenges of Eco-label Practices in Bangladesh for Promoting Environmentally Conscious Consumers
}

\author{
Aminul Haque Russel and Lakkhan Chandra Robidas
}

\begin{abstract}
Environmental degradation is a significant issue all over the world. In order to mitigate the environmental concerning issues, there is a need to develop policies in multidiscipline. Eco-label is one of them. The purpose of this research paper is to demonstrate the opportunities and challenges of Eco-label practices in Bangladesh for promoting environmentally conscious consumers. In order to meet the research objective, the descriptive method, in the form of observation and interview was adopted. The study identified that eco-label practices has some challenges like unawareness of customer about eco-label, lack of unified standard criteria and principles, unclear or misrepresentation of eco-label declaration, no authorized body and absence of expert for design \& assessment of eco-label as well as it has create opportunities i.e. gain competitive advantage and products differentiation, create brand image and impression in national \& international markets. Finally, it's possible to educate consumers \& build attitudes among them towards eco-friendly consumption.
\end{abstract}

Index Terms- Environmental degradation, Eco-labeling, environmentally conscious consumers.

\section{INTRODUCTION}

The world is enlightened by the hand of industrialization. Industrialization creates various positive issues for the world on the other side which is massively responsible for environmental degradation like, threat in bio-diversity, global warming and climate change. There are generally two types of business organization one is manufacturing and another services oriented. Manufacturing organizations has direct impact on environment. That impact is start on production methods in all types of industry like, food and beverage industry, textile industry, leather industry etc. produce negative externalities through the entire production process and to end-of-product life. However, in the context of Bangladesh, producer is not concerned about the impact of packaging after using the products by consumers or any other scrap parts of the products as well as consumer is not conscious about their role.

An emerging issue in environmental management studies is the role of eco-labels in guiding consumers in their purchasing choices (Testa et al., 2013). Environmentally conscious consumer behaviour is getting significant

Published on16 December 2019.

Aminul Haque Russel, Department of Business Administration, Daffodil Institute of IT, Dhaka, Bangladesh.

(e-mail: aminul_nu@diit.info)

Lakkhan Chandra Robidas, Department of Business Administration, Daffodil Institute of IT, Dhaka, Bangladesh.

(e-mail: lakkhan_nu@diit.info) consideration in formulating the marketing strategy or policies (Lin \& Hsu, 2013). The use of an easy-to-interpret but standardized and comprehensive environmental information label increases the eco-friendly consumption (Vlaeminck et al., 2014). Furthermore eco-labels reduce consumers' information search costs and effort as well as promote recycling behavior. There is a growing empirical literature dealing with different aspects of eco-labels where most studies focus on the market impact of eco-labelled products (Hornibrook et al., 2015; Sammer \& Wüstenhagen, 2006) and consumers' comprehension, perception, and misperception of eco-labels (Brécard, 2015; Steinhart et al., 2013). There is a clear gap in exploring the challenges and opportunities of eco-labels practices to build an environmentally conscious consumer behavior among the public other than demand and/or purchasing of eco-labelled products. This is essential to examine because intend of ecolabels is not only promoting eco-labelled products, but also to promote other aspects of environment friendly consumer behavior.

\section{LITERATURE REVIEW}

Fundamentally, eco-labeling provide consumers with information about the environmental quality of individual products, at the time of purchase to assist them to choose products that are acceptable from an environmental point of view (Thøgersen et al., 2010). (Bruce and Laroiya, 2007) described an eco-label as a claim prepared by a firm, confirming that 'it has employed environmentally-sensitive production or distribution methods'. It is a voluntary approach to environmental certification practiced around the world and is developed by governments, manufacturers, and third-company organizations independently. A product that meets or qualifies wide range of environmental performance criteria or standards is recognized by an eco-label. (Taufique, K.M.R. et.al, 2015), concluded that eco-label is an environmental communication tool that informed to the consumers about general environmental knowledge and ecolabel knowledge because both have a significant positive effect on ecologically conscious consumer behavior. (D'Souza et al. 2006) found that environmental labels are more and more being accepted as an important market tool for identification of green products. Eco-labeling has an influence given a message on labels, such as, environment-friendly, ozone-friendly, earth-friendly, degradable, recycled, recyclable, renewable, and reusable or for that matter biodegradable. Although, consumers make choices based on other decision criteria, product labels provide an informative base for a consumer to make 
choices. Environmental labels act as a guide for consumers to choose products that are environmentally friendly. It is often used by businesses to differentiate their products, position them and communicate the environmentally friendly message (D'Souza, 2000). There are a number of ways by which marketers convey environmental benefits of products, one is through general or specific product claims on product labels, for example, "eco-friendly", "environmentally safe", "recyclable", "biodegradable" and "ozone-friendly" (Morris et al., 1995). The eco-labeling system is complicated for consumers because it is composed of a set of production standards, a certification system, and a labeling scheme (Boström \& Klintman, 2008). Eco-labels tend to be a crucial factor to influence consumers' purchase decision when a green product is relatively expensive or lower quality (Joshi \& Rahman, 2015). From a marketing policy perspective, eco-labelling is a promotional and/or communication tool that is meant to provide consumers with environment-related product-specific information, assisting them in making greener purchasing decisions (Rettie, Burchell, \& Riley, 2012). (Erskine and Collins, 1997), identified that there is little evidence shows currently ecolabeling bring benefits for environment. Environment labeling programmes help consumers to make informed about the products that they buy as well as to inform them of the environmental impact of those products throughout their life cycle. (Salman, 2016) concluded that eco-labeling is a new dimension or a useful tool to consumers for making decision to purchase the environmental friendly products. Accordingly, success or failure of an eco-label greatly depends on consumer awareness or role. He also, gave an overview of eco-label with its advantages and limitations and practices of eco-label in all over the world.

\section{OBJECTIVES OF THE STUDY}

The broad objective of this research paper is to demonstrate the opportunities and challenges of Eco-label practices in Bangladesh for promoting environmentally conscious consumers. The other objectives are given below:

a. To understand the concept of eco-label.

b. To identify the opportunities and challenges of ecolabel practices.

c. To show the scenario of eco-label practices in Bangladesh.

\section{RESEARCH METHODOLOGY}

This paper is a descriptive type of research which has been conducted based on the primary $\&$ secondary data and followed interviews of 30 consumers and 5 marketers by using unstructured questionnaire and the interviews were conducted in Bengali, the then pertinent information was translated into English. In total, 300 different types' goods [like, food \& beverage, stable \& impulse goods, electronics etc.] were selected by using a convenient random sampling technique. Data were collected from various super shops and retail stores in the Dhaka city by using structured observation of sign, image, logo, and symbols which indicates eco-label standard in the goods. After that, we separate on the basis of different terminology using by marketers to convey environmental benefits of products, one is through general or specific product claims on product labels, for example, "reuse", "landfill", "eco-friendly", "green seal", "eco+", "environmentally safe", "recyclable", "greenhouse gas", "ISO certification", "keep your country clean", "biodegradable" and "ozone-friendly".

\section{OUTLOOKS OF ECO-LABEL}

\section{A. Meaning and Types of Eco-label}

According to Global Eco-labeling Network (GEN, 2004), "Eco-labeling" is a voluntary method of environmental performance certification and labeling that is practiced around the world. An eco-label identifies products or services proven environmentally preferable overall, within a specific product or service category and this information indicates how goods "cause less stress on the environment".

An eco-label is a seal or symbol or logo conveys information about a product that meets a wide range of environmental performance criteria of standards in production process even after end-use of life. It is developed by government, manufacturers and third party or company. It is typically voluntary approach but may be mandatory in certain cases to environmental certification practices around the world. (Rotherham, 1999), defined that "eco-labeling" refer to information a product provides about the environmental impacts associated with the production or use of product. (Heimbach and Stokes, 1982) reports that consumers find label information relating to known public health problems were the most useful. Therefore, an ecolabel is a visual communication tool indicating environmentally preferable products, services or companies that are based on standard or criteria. (Taufique, et al., 2014) described that eco-labelling is to identify the factors that support the consumers' for assessing the eco-labels.

Eco-labeling concept was first formulated Germany in 1978. The formal implication was started in 1978. The Blue Angel labeled over 4000 thousands products on voluntary basis to conform the value offered for consumers are environment friendly and safe. Followed European Union in 1992 to assure production and consumption of products are healthy (Renate Gertz, 2005, and Smith. A. \& Stancu.C. 2006).

The International Standard Organization (ISO), as part of its ISO 14000 series of environmental standards, has classified environmental labels. Also, in Australia, the report prepared by a sub-committee of the Strategic Advisory Group on the Environment (SAGE, 1993) developed a classification system to distinguish between third party ecolabelling schemes. In the report of SAGE, it was recommended that a classification system be developed to differentiate between labels that were part of a third party eco-labelling scheme and claims that were put on products by manufacturers. These categories included types I, II and III environmental labelling.

Consumers on a daily basis are exposed to type II labelling with messages on labels, such as, environmentfriendly, ozone-friendly, earth-friendly, degradable, recycled, recyclable, renewable, reusable or for that matter biodegradable. Unlike other physical attributes of a product, environmental attributes are difficult to detect unless there is sufficient information about them. Owing to this difficulty 
in detecting green attributes, consumers rely on visual factors such as media advertising and/or information provided on product labels. Table 1 shows the outline of the ISO-defined labels and what is being claimed in each type of label.

TABLE 1: ISO-DEFINED TYPES OF GREEN PRODUCT CERTIFICATION LABELS

\begin{tabular}{|c|c|c|}
\hline Type & ISO Number & Label Signify \\
\hline Type I & ISO 14024 & $\begin{array}{l}\text { Seal of approval for voluntary, multiple- } \\
\text { criteria based, third party programme that } \\
\text { awards a license which authorizes the use } \\
\text { of environmental labels on products } \\
\text { indicating overall environmental prefer } \\
\text { ability of a product within a particular } \\
\text { product category based on life cycle } \\
\text { considerations. }\end{array}$ \\
\hline Type II & ISO 14021 & $\begin{array}{l}\text { Verifiable single-attribute environmental } \\
\text { claims for issues such as energy } \\
\text { consumption, emissions, or recycled } \\
\text { content. Can be first-party, self-declared } \\
\text { manufacturer claims. }\end{array}$ \\
\hline Type III & ISO $>14025$ & $\begin{array}{l}\text { Comprehensive environmental product } \\
\text { disclosure and detailed product } \\
\text { information. Similar to an Environmental } \\
\text { Product Declaration (EPD) whose awarding } \\
\text { is based on a full life-cycle assessment. }\end{array}$ \\
\hline
\end{tabular}

Source: WBDG website, http://www.wbdg.org/resources/green-buildingstandards-and-certification-systems

\section{B. Eco-labelling around the world}

Eco-labelling is a vital marketing communication tool that provides the environmental information to the consumers. On the supply side, the number of products that obtained eco-labels has increased during the past years.

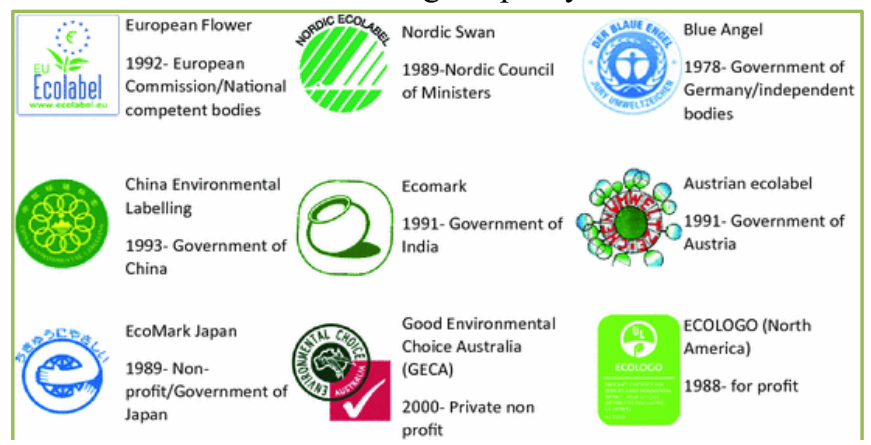

Sources: Frydendal, J., et.al (2017)

For example, the EU eco-label 'The Flower' awarded only six licenses in 1996, an additional 128 in 2002, and a further 754 in 2008 . There are approximately 463 eco-labels in 199 countries and 25 industry sector (Source: WWW.ECOLABELINDEX.COM). On the demand side, based upon the recent Flash Euro barometer 258 study, it was found that for approximately $50 \%$ of European citizens, eco-labels play a significant role in their consumption decisions (Taufique, K.M.R., et. al, 2014). There are few renowned eco-labelling used by different nations around the globe.

\section{Eco-labelling in Bangladesh}

According to Eco-label Index, Bangladesh currently have only 6 international standard eco-labels in market (Eco-label index, 2017).
Table 2: ECO-LABELLING SCHEME IN BANGLADESH Activities

Certification
Industry
Category
$\begin{gathered}\text { Retail } \\ \text { packaging of } \\ \text { seafood }\end{gathered}$
$\begin{gathered}\text { Travel and } \\ \text { tourism }\end{gathered}$

clean, safe, prosperous and healthy destinations for travellers to visit, live, work and play.

The Global Organic Textile Standard (GOTS) that ensure organic status of textiles, from harvesting of the raw materials, through environmentally and socially responsible manufacturing up to labelling in order to provide a credible assurance to the end consumer.

The Institute for Market ecology (IMO) is an international agency for inspection, certification and quality assurance of eco-friendly products.

The Programme for the Endorsement of Forest Certification (PEFC) is an international nonprofit, non-governmental organization. It works by endorsing national forest certification schemes developed through multistakeholder processes, rigorous third-party assessment and tailored to local priorities and conditions.

TCO Certified is an international sustainability certification for IT products and includes a wide range of criteria ensuring that the manufacturing, use and recycling of IT products is carried out with regard to environmental and social responsibility.

Source: http://www.ecolabelindex.com/ecolabels/?st=country,bd

\section{Scenario of Eco-label Practices in Bangladesh}

For representing the Eco-label practice in Bangladesh, we have physically gone through different superstores to evaluate whether the companies are using eco-label or not. In this regard we selected 300 items are the combination of same type's goods of different companies and also different types of goods of same companies packaged consumer goods like staple, impulse and shopping goods.

\section{TABLE 3: ECO-LABEL DECLARATION BY SELF \& THIRD PARTY}

\begin{tabular}{|l|c|c|}
\hline \multicolumn{1}{|c|}{ Eco-label } & N (300) & Percentage (\%) \\
\hline Recycle & 48 & 14.25 \\
\hline Reuse & 7 & 2.08 \\
\hline Landfill & 131 & 38.87 \\
\hline Green Seal & 69 & 20.47 \\
\hline Eco+ + & 8 & 2.38 \\
\hline Environment Friendly & 3 & 0.89 \\
\hline Greenhouse gas & 5 & 1.48 \\
\hline ISO certification & 61 & 18.1 \\
\hline Keep your country clean & 5 & 1.48 \\
\hline Total & 337 & $100 \%$ \\
\hline
\end{tabular}




\section{Source: Authors observation}

We have seen from the observation that most of the companies are practicing self-declared or third party certification. It is found that couples of companies are using multiple seal or logo or eco-label certification in the same category of consumer goods package. We have also seen from the observation that there is no clear description in packaging of goods about recycle, reuse, and landfill procedure i.e in what ratio, how \& when it will be reused, recycled \& mix with land.

\section{E. Benefits of Eco-label for Consumers}

Eco label has confirmed to be an effective instrument in raising awareness and trust among consumers that a company has strived to be sustainable (Watanatada, 2011). Eco-labeling can generate change in consumer attitude towards more eco-friendly consumption patterns by providing consumers with information about the environmental effects of their consumption (Galarraga, 2002). Eco-labeled products are environmentally preferable products with compared to other products in the same category (Loureiro et al. 2001; Galarraga, 2002). Consumers need knowledge about production standards that underly eco-label to distinguish eco-labeled from non-eco labeled products (Thøgersen, 2000). Consumers' needs for ecolabeled rice can be transformed into preferences for green or organic labels (Boström \& Klintman, 2008). Eco-labels are effective only if they have real effects on consumer's decision-making (Daugbjerg, 2014). It acts as a guide for consumers to choose products that reduce environmental impact (D'Souza, 2000; Rex \& Baumann, 2006) and enables them to influence how the product is manufactured (Rex \& Baumann, 2006). It assures consumers of the truthfulness of these claims by providing certification marks or seals of approval (Atkinson \& Rosenthal, 2014).

\section{F. Benefits of Eco-label for Producers/Marketers}

According to Treves and Jones (2010), labels on products are powerful marketing tools that act as essential communication conveyers between businesses, public authorities, and consumers. In addition to labelling information it is also corporate reputation that lends itself to determining social and environmental responsiveness of businesses (D'Souza et al., 2004). As in this era of corporate reputation, researchers have found that "consumers increasingly make purchases on the basis of a firm's role in society" (Forte and Lamont, 1998). (Dagnoli, 1991) found that 77 per cent of those surveyed also reported that a company's environmental reputation influenced their choice of brands. Green corporate perception, therefore, may potentially act as a catalyst towards environmental labelling. (Koos, 2011) states that environmental labels are conveyed to consumers a sense of environmental consideration on the part of the manufacturer. Many businesses also use ecolabels to differentiate their products to ensure an increase in market share as environmentally conscious consumers are attracted to it (Brécard et al. 2009). Businesses can ask a price premium for their certified eco-labelled products (Delmas and Grant 2014). Eco-labels provide producers with a tool for product differentiation and which results in market place preference which ultimately leads to an increase in market share for businesses (Rashid 2009).
Consumers' overall perceived image of the company is increased (Albu and Chitu 2012). Certain eco-labelling programmes act as market access requirements for specific industries and as such it could be more difficult for competitors, who do not adhere to these certification programmes, to enter the specific industry (Carlson and Palmer 2016). Therefore, the consumer's perception of the business's corporate strategies towards environmental issues is expected to contribute to the formation of the overall perception of green products. Eco-labelling encourage producers to invest in more sustainable agricultural practices (Galarraga, 2002).

\section{G. Eco-labelling: Opportunities for Bangladesh}

The main purpose of eco-labelling schemes is to distinguish certain brands of products with less adverse environmental impact than others in the same product category (UNCTAD, 1994). Thus, eco-labelling may be seen as an important tool for gaining access to 'green' markets. For those producers willing and currently or potentially able to meet the sustainability requirements, ecolabelling presents an opportunity to add value to existing products, expand reach in existing markets, or maintain market share in a competitive environment.

Eco-labelling can also provide an opportunity for innovative producers to gain benefit from the use of more environmental friendly production methods (Downes and Dyke, 1998). This business practices may differentiate the products and help to gain competitive advantages for exporters of Bangladesh to enhance their export earnings.

From the company's viewpoint, eco-labels are helpful to carve out a distinct market position through sustainable promotion and build economically, socially and environmentally conscious consumers.

The company may generate higher revenue and the potential growth of market share by entering into both industrial and developing countries; if they comply with the certification criteria i.e eco-label in the business practices because which is convincing business policy.

Now, all country and the international business community are concerned about environmental issues for that reason business start to consider environmental matter in their policy like production to consumption even in products packaging. Eco-labelling scheme is one of the best tools that will help them to fulfill the commitments made by different international body on environment that will create a good impression in the international market.

The eco-labeling will reduce uncertainty about the environmental performance of products and enable consumers to choose products that cause less damage to the environment.

Eco-labels may potentially enhance the trade for those developing countries which is able to accurately translate the mood of industrialized country consumers into environmentally friendly product development nation.

To implement the understandable environmental policy and market based tools for energy efficiency and conservation in the near future. This is possible to increase demand for more energy efficient products and services such as greener energy products, building design, or power. 
In this circumstance, eco-labelling plays an enormous role to reduce the total greenhouse gas emissions.

In other products such as textiles, leather products, and garments are some of the main export oriented products in Bangladesh and would benefit from the eco-labelling schemes. Because there is an increasing pressure on the developing countries to adapt eco-labelling requirements as the consumers are gradually making preferences especially while buying clothing and textile products produced in environment friendly condition.

Marketers believe that eco-labelling could provide new opportunities for attracting capital investment and joint ventures with developing countries.

\section{H. Eco-labelling: Challenges for Bangladesh}

Some companies may intentionally misrepresent the label as "environmentally friendly" in the products labeled in order to boost-up the profits. This accounts for unfair business competition for those firms spending time and money for maintaining the regulations. It is also observable that sometimes consumers are not interested to rely on those brands which take certification from other country.

Unregulated proliferation of labels issued by many bodies or authorities tends to deteriorate the significance of ecological labeling. Not all eco-labels have a solid verification scheme, a process of setting transparent standards or scientifically validated criteria.

Limited environment relevant information disclosure and representation about eco-label may form misconception or indecision in the buying process of consumers.

The lack of expertise, financial and organizational capacity creates obstacle to conduct the design, assessment and transform their production procedures into more environment friendly products.

When claims are made randomly in advertising and labeling, customers will become confused, discouraged, and doubtful - even about the legitimate claims. Due to this reason eco-label cannot create value to the environmentallyconscious customer.

Although marketers are using seal, sign and symbol in the eco-label to proof environmentally friendly product which may restrain the customer to buy the products. It happens due to the unawareness of the customer about those seal, sign and symbol.

Many environmentalists are serious of consumerism. They argue that 'green consumerism' is a self-contradicting term, and believe that the goal should be to diminish consumption, not just redefine it. 'Green shopping' will do slight to bring about the more fundamental economic and social changes that are required to protect the planet, they claim.

Another anxiety is that only a small number of products can realistically be labeled as 'green'. Since the vast majority of goods will not be covered by eco-labeling programs, some critics point to regulation as a more effective tool than the development of voluntary standards.

\section{FINDINGS \& RECOMMENDATIONS}

To convey accurate, comprehensive and reliable information for understanding and building trust among consumers.

Major challenges include improving credibility and increasing user-friendliness of the eco-labels. The plenty of similar labels in the market tends to confuse customers, weakening the trust and credibility of the scheme. Tackling this problem includes limiting the number of labels and regulating and harmonizing the awarding procedures.

Simplicity in the certification procedures may minimize the administrative burden on producers.

To make the labelling system effective, the government needs to arrange the different public programs for making the system credible and acceptable.

The certification principles of eco-labels need to be uniformed and specific to bring out the desired performance.

Moreover, many governments around the world and industry groups recognize that eco-labeling could provide needed economic incentives for better long term stewardship and availability of natural resources important for national economic welfare.

Regulatory body needs to develop guidelines and regulations about eco-labeling to promote environmentally conscious consumers and marketers.

Eco-labeling awareness promotion activities need to spread in all geographic areas in Bangladesh (Like - Rural, Sub-urban \& Urban) for achieving the sustainable goals.

\section{CONCLUSION}

Eco-Labeling is still new in Bangladesh and the concept is not very familiar to the public or to the business community. In order to make this concept known, issues related to eco-labeling should be disseminated with a view to encourage production and consumption of environmentally-friendly products, raise awareness of environmental protection and relate this to economic benefits of enterprises. Finally, from marketing viewpoint, labeling is one strategy to provide information so that consumers to be able to assess a product's environmental identifications, and to be able to compare them with those of competing products. By communicating specific social or environmental benefits, eco-labels help consumers make more informed purchase decisions and play a potential role in the development of sustainable marketing.

\section{REFERENCES}

Albu RG, Chitu IB. (2012). The European Ecolabel - Advantages and perspectives for development in Romania. Bulletin of the Transilvania University of Brasov. Economic Sciences Series, 5 (2): 9-14.

Atkinson, L. \& Rosenthal, S. (2014). Signaling the Green Sell: The Influence of Eco-Label Source, Argument Specificity, and Product Involvement on Consumer Trust, Journal of Advertising, 43:1, 33-45, DOI:10.1080/00913367.2013.834803

Boström, M.; Klintman, M. (2008). Green Labels and Other EcoStandards: A Definition. In Eco-Standards, Product Labelling and Green Consumerism; Palgrave Macmillan UK: London, $U K$, pp. 27-32. 
Bruce, Christopher and Laroiya, Andrea (2007), the Production of Eco-Labels. Environmental and Resource Economics, 36 (3), 275-293.

Brécard, D., Hlaimi, B., Lucas, S., Perraudeau, Y., \& Salladarré, F. (2009). Determinants of demand for green products: An application to ecolabel demand for fish in Europe. Ecological Economics, 69 (1): 115 125 .

Brécard, D., (2015). Consumer Misperception of Eco-labels, Green Market Structure and Welfare. FAERE Working Paper, 2015

Carlson, A., \& Palmer, C. (2016). A qualitative meta-synthesis of the benefits of eco-labeling in developing countries. Ecological Economics, 127(1): 129-145.

Dagnoli, J. (1991). "Consciously green". Advertising Age, Vol. 14.

Daugbjerg, C., Smed, S., Andersen, L.M., \& Schvartzman, Y. (2014). Improving eco-labelling as an environmental policy instrument: Knowledge, trust and organic consumption. J. Environ. Policy Plan. $16,559-575$

Delmas MA, Grant LE (2014) Eco-labeling strategies and price-premium the wine industry puzzle. Business and Society 53 (1): 6-44.

D'Souza, C. (2000), "Bridging the communication gap: dolphin safe ecolabels", Corporate Communication: An International Journal, 5(2), pp. 185-90.

D’Souza, C., Taghian, M. and Lamb, P. (2004), “A review of the green customers' perception formation about environmentally safe products", Proceedings in Australia and New Zealand Marketing Academic Conference, Marketing Accountabilities and Responsibility, Wellington, 29 November-1 December.

D'Souza, Clare, Mehdi Taghian, and Peter Lamb (2006), An empirical study on the influence of environmental labels on consumers, Corporate Communications: An International Journal, (11), 2, pp.162-173.

D. Downes \& B. Van Dyke. 1998. Fisheries Conservation and Trade Rules: Ensuring that Trade Law Promotes Sustainable Fisheries, Centre for International Environmental Law and Greenpeace: Washington, D.C. p.33.

Erskine, C.C. \& Collins, L. (1997). Eco-labelling: success or failure? The Environmentalist, 17, 125-133. https://doi.org/10.1023/A:101855200065 http://www.ciel.org/Publications/fisheriesconservation.pdf

Forte, M. and Lamont, B. (1998), "The bottom-line effect of greening (implications of ecological awareness)", The Academy of Management Executive, 2(1), pp. 89-91.

Frydendal J., Hansen L.E., Bonou A. (2018) Environmental Labels and Declarations. In: Hauschild M., Rosenbaum R., Olsen S. (eds) Life Cycle Assessment. Springer, Cham

Galarraga Gallastegui, I. (2002). The use of eco-labels: A review of the literature. Eur. Environ. 12, 316-331.

Gertz, R. (2005). Eco-labelling--a case for deregulation? Law Probability and Risk, 4(3), 127-141.

Global Ecolabelling Network (GEN). (2004). Introduction to Ecolabelling. Information Paper. Retrieved from [WWW. document] http://www.globalecolabelling.net/docs/documents/intro to ecolabell ing.pdf

Hornibrook, S., May, C., Fearne, A., 2015. Sustainable Development and the Consumer: Exploring the Role of Carbon Labelling in Retail Supply Chains. Business Strategy and the Environment 24(4), 266276.

Heimbach, J.T. and Stokes, R.C. (1982), "Nutrition labeling and public health: survey of American Institute of Nutrition members, food industry, and consumers", The American Journal of Clinical Nutrition, 36, pp. 700-8.

ISO 14024. (1999). Environmental labels and declarations-Type I environmental labelling-Principles and procedures. Reference number ISO 14024. 1999(E).

ISO. (2012). Environmental labels and declarations: How ISO standards help.[WWW.dcoument].URL//www.iso.org/iso/environmental-labelli ng.pdf

Joshi, Y.; Rahman, Z. (2015). Factors affecting green purchase behaviour and future research directions. Int. Strategy. Manag. 3, 128-143.

Koos, S. (2011). Varieties of Environmental Labelling, Market Structures, and Sustainable Consumption Across Europe: A Comparative Analysis of Organizational and Market Supply Determinants of Environmental-Labelled Goods. Journal of Consumer Policy, 34, (1), 127-151.

Lin, H. Y., Hsu, M. H., 2015. Using Social Cognitive Theory to Investigate Green Consumer Behavior. Business Strategy and the Environment 24 (5), pp. 326-343. https://doi.org/10.1002/bse.1820

Loureiro, M.L.; McCluskey, J.J.; Mittelhammer, R.C. (2001). Assessing consumer preferences for organic, eco-labeled, and regular apples. $J$. Agric. Resour. Econ. 26, 404-416.

Morris, L., Hastak, M. and Mazis, M. (1995), “Consumer comprehension of

environmental advertising and labelling claims", The Journal of Consumer Affairs, 29 (2), pp. 328-51.

Rettie, R., Burchell, K., \& Riley, D. (2012). Normalising green behaviours: A new approach to sustainability marketing. Journal of Marketing Management, 28, 420-444. https://doi.org/10.1080/02672 57X.2012.658840

Rex, E., \& Baumann, H. (2006). Beyond Ecolabels: What Green Marketing Can Learn From Conventional?

Rashid NRNA (2009) Awareness of eco-label in Malaysia's green marketing initiative. International Journal of Business and Management, 4 (8): 132-136.

Rotherham, T. (1999), "Meeting of Technical Specialists and Policy Expertson Environmentally-Sound Trade Expansion in the Americas. Selling Sustainable Development: Environmental Labeling and Certification Programs, University of Miami, October 28-29", available at: www.iisd.org/standards/pdf/miami paper final.pdf (accessed March 25, 2009).

Salman.M.M (2016), Eco-labels: Tools of Green Marketing, International Research journal of Management of Sociology \& Humanity, 7(5), pp 16-23.

Sammer K., Wüstenhagen, R., 2006. The Influence of Eco-labeling on Consumer Behaviour - Results of a Discrete Choice Analysis for Washing Machines. Business Strategy and the Environment 15, 185-199.

Stancu, C., \& Smith, A. (2006). Food miles - The international debate and implication for New Zealand exporters. Landcare Research, Business and Sustainability Series, Briefing Paper 1.

Steinhart, Y., Ayalon, O., \& Puterman, H. (2013). The effect of an environmental claim on consumers' perceptions about luxury and utilitarian products. Journal of Cleaner Production, 53, 277-286. http://dx.doi.org/10.1016/j.jclepro.2013.04.024

Taufique, K. M. R., Siwar, C., Talib, B., Sarah, F. H., \& Chamhuri, N. (2014).Synthesis of constructs for modeling consumers' understanding and perception of eco-labels. Sustainability, 6, 2176-2200. https://doi.org/10.3390/su6042176

Taufique, K. M. R., Siwar, C., Chamhuri, N., Sarah, F. H., 2015. Integrating General Environmental Knowledge and Eco-Label Knowledge in Understanding Ecologically Conscious Consumer Behavior. Procedia Economics and Finance 37 (2016), 39 - 45.

Thøgersen, J. (2000). Psychological determinants of paying attention to eco-labels in purchase decisions: Model development and multinational validation. J. Consum. 23, 285-313.

Thøgersen, J., Haugaard, P., \& Olesen, A. (2010). "Consumer responses to ecolabels". European Journal of Marketing, 44 (11/12),1787-1810,https://doi.org/10.1108/03090561011079882

Treves A, Jones SM (2010) Strategic tradeoffs for wildlife-friendly eco-labels. Frontiers in Ecology and the Environment 8 (9): 491-498.

Testa, F., Iraldo, F., Vaccari, A., Ferrari, E., 2013. Why Eco-labels can be Effective Marketing Tools: Evidence from a Study on Italian Consumers. Business Strategy and the Environment 24(4), 252-265.

UNCTAD, (1994). Eco-Labelling and Market Opportunities for Environmentally Friendly Products, TD/B/WG.6/2. UNCTAD: Geneva

Vlaeminck, P., Jiang, T., Vranken, L., 2014. Food Labeling and Ecofriendly Consumption: Experimental Evidence from a Belgian Supermarket. Ecological Economics 108, 180-190.

Watanatada, P. (2011, March 10). Questioning and evolving the ecolabel. Retrieved June 23, 2014 from http://www.theguardian.com/sustainablebusiness/blog/questioning-evolving-the-ecolabel. http://www.ecolabelindex.com/ecolabels/?st=country,bd

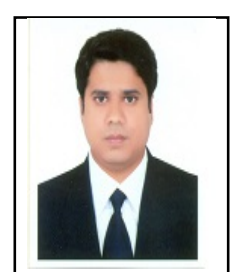

finance, Green Bank
Aminul Haque Russel is Senior Lecturer, Department of Business Administration at the Daffodil Institute of Information and Technology(DIIT), Dhaka, Bangladesh. He finished Bachelor of Business Administration, major in Finance, from National University of Bangladesh and holds MBA from Daffodil International University, Bangladesh, major in Finance. He wrote several articles and published three books. Haque's area of interest includes Green , Financial Inclusion and Fintech. 
Lakkhan Chandra Robidas is currently Assistant

Professor \& Head of Department of Business Administration at the Daffodil Institute of Information and Technology(DIIT), Dhaka, Bangladesh. He

finished Bachelor of Business Administration, major in Marketing, from National University of Bangladesh and holds MBA from Daffodil International University, Bangladesh, major in Marketing. He wrote several articles and published two books. Robidas's area of interest includes Green Marketing, Green marketing promotion,Green Consumer Behavior and Technology in Marketing. 